\title{
STUDIES ON THE MAIN CHEMICAL COMPOSITION OF BONES
}

\author{
L. Paloheimo, L. M. BJörkenheim, and H. Leivonen \\ Department of Animal Husbandry, University of Helsinki
}

Received January 2, 1965

Analysing the entire bodies of three dairy cows Palohermo (2, p. 1) noticed that the fat content of the bones did not run parallel with the fat content of the whole body. The bone-free body of one of the cows contained $25.2 \%$ fat, the corresponding figure of the skeleton being 19.9, while the second cow gave the figures 15.5 and 22.0 respectively, and the third 14.7 and 19.0. Another 23 cows were analysed less exhaustively. The fat was determined from skeletal musculature, superficial adipose tissue, peritoneum, and adipose tissue round the organs. In

Table 1. The composition of cow's femur (Paloheimo 2, p. 45).

\begin{tabular}{|c|c|c|c|c|c|c|}
\hline \multirow{2}{*}{$\begin{array}{l}\text { No. of } \\
\text { cow }\end{array}$} & \multirow{2}{*}{$\begin{array}{l}\text { Age } \\
\text { years }\end{array}$} & \multirow{2}{*}{$\begin{array}{l}\text { The deter- } \\
\text { mined fat } \\
\% \text { of } \\
\text { the body }\end{array}$} & \multicolumn{4}{|c|}{$\%$ in femur } \\
\hline & & & Fat & Protein & Ash & Water \\
\hline 26 & 8 & 19.6 & 30.9 & 15.0 & 33.3 & 20.8 \\
\hline 23 & 9 & 18.8 & 36.4 & 14.7 & 31.8 & 17.1 \\
\hline 25 & 7 & 16.0 & 31.4 & 15.4 & 32.7 & 20.5 \\
\hline 24 & 12 & 12.1 & 35.4 & 15.2 & 31.2 & 18.2 \\
\hline 22 & 13 & 10.5 & 36.4 & 14.3 & 31.0 & 18.3 \\
\hline 21 & 9 & 10.3 & 34.7 & 14.7 & 31.8 & 18.8 \\
\hline 20 & 13 & 4.2 & 32.5 & 14.6 & 30.6 & 22.3 \\
\hline
\end{tabular}

Table 1 this fat as percentage of the whole body is found under the heading "The determined fat». In seven cows the right thigh bone (femur) was analysed and the results are shown in Table 1. It appears that the fat content of the femur does not vary much and is apparently not correlated with the fatness of the cow. 
As the number of cows in the referred investigation was rather small, and as we have not found any papers on the same subject, we decided to analyse a somewhat greater number of cow femurs, especially for the purpose of establishing whether there really is a lack of the above mentioned correlation.

\section{The animals}

Twenty of the investigated animals were adult cows. Seventeen of them were Ayrshire cows and 3 of Finnish breed. In addition, there were a young heifer, a calf 4 months old, a calf 2 days old, and a calf which was born dead though fully developed. Three of the Ayrshire cows and all the young animals came from the University farm. The rest of the cows were slaughter-house animals. Excepting the cow No. 21, all animals appeared to have healthy organs. Cow No. 21, from the University farm, was a sick animal with morbid changes in the liver, kidneys and heart muscle.

The animals were weighed before slaughtering, and the weight of the carcass was also established. Before the slaughtering the grade of fatness was estimated according to a system used in our department. In this the cows are graded into 7 classes, the fattest ones belonging to class I and the emaciated ones to class VII. The day after slaughtering the right femur was removed, put in a plastic bag, and taken to the laboratory where it was kept in the refrigerator until its analysis. From four of the cows also the right tibia was removed.

\section{The analysis}

a) The bone which has been kept in the refrigerator enclosed in a plastic bag is without delay scraped free from all flesh and tendons. It is then weighed and sawn in 3 fragments which are put in a saucepan and covered with destilled water.

b) The saucepan is put in an autoclave and heated there in $125^{\circ} \mathrm{C}$ for 4 hours. When the temperature has gone down below $100^{\circ}$ the saucepan is taken out from the autoclave, the bone fragments are removed by help of tongs and put in another saucepan. The inside of the bone fragments is now practically free from fat and the fragments are quite brittle.

c) The bone fragments are crushed in the second saucepan, water is added and the contents boiled for one hour. The rest of the fat rises to the surface and is easy to remove after the saucepan has been kept in the refrigerator. It is put into the first saucepan which contains the bulk of the fat. The liquor above the crushed bones is decanted into a large beaker and water is added into the saucepan which is again boiled for one hour. The fat is removed as above and the liquor decanted into the above mentioned beaker.

d) The crushed bones are removed into an ignated and weighed porcelain dish and dried in a desiccator. After weighnig, the dish with the crushed bones is kept in an ashing oven at $550^{\circ} \mathrm{C}$ until the bone pieces are quite white. Then the dish is cooled in an exsiccator and weighed. 
e) The saucepan which was kept in the autoclave (point b) is cooled in a refrigerator and the fat is removed into a large beaker. The very small portion of fat obtained by the procedures described in point $g$ is added to the main fat. The fat is now washed in the beaker. Plenty of water is added and heated to boiling point under vigorous stirring. Then the beaker is cooled in the refrigerator and the fat cake, the weight of which is about $500 \mathrm{~g}$, is removed into a weighed steel crucible. In this procedure the use of a cork screw is advisable. Since after the washing some of the non-fat particles liberated from the fat will adhere to the lower surface of the fat layer in the beaker, it is advisable to let some alcohol flow from a pipette below the fat layer.

f) The steel crucible with the fat is heated under constant stirring with a weighed thermometer. The temperature must be about $125^{\circ}$. The heating is continued until the bubbling has ended and the fat in the crucible lays quite still. The crucible with the thermometer and the fat are then cooled in the exsiccator and weighed.

g) The different cooking and wash waters which contain the bulk of the bone protein and some bone crumbs are poured through a sieve (din 12) into a weighed pail and the pail with the filtrate is weighed. Directly after mixing thoroughly a $2 \mathrm{~kg}$ sample is taken and put in a porcelain dish. From the material retained on the sieve the fat is extracted by boiling it in alcohol. The aliquot of the residue is taken and put in the above mentioned porcelain dish. This aliquot should be the same as the $2 \mathrm{~kg}$ was of the whole filtrate. The water is evaporated from the dish first on a Bunsen flame and then over a water bath.

h) The material in the above mentioned dish, mostly bone glue, is removed into a smaller weighed dish and dried in a drying oven. After weighing the material is ground fine and kept for a time in a shallow plate for obtaining a balanced moisture content. The samples are taken for a determination of water, ash, and nitrogen.

i) The composition of the bone is calculated in the following way:

1) The weight of the fat is obtained by direct weighing (point f).

2) The weight of the ash is obtained as the sum of the ash of cooked bone residues (point d) and the ash of cooking and wash waters (points $g$ and $h$ ). 3) The weight of the bone glue (protein) is obtained as the sum of the incineration loss of the cooled bone residues (point d) and the incineration loss of the dry matter of the cooking and wash waters (point $g$ and $\mathrm{h}$ ).

4) The weight of the water is obtained by subtracting the above weights from the weight of the bone (point a).

5) The percentages are calculated as percent of the cleaned bone (point a). 6) The described analysis does not afford the calculation of the nitrogen content of the whole bone protein but only of the nitrogen content of the organic matter in cooking and wash waters (point h) which contain the bulk of the bone glue.

\section{Results and discussion}

The principal results pertaining to the cow femurs are shown in Table 2. In this the cows are enumerated according to the fat percentage of the femur. Cow No. 21 was the sick one (see p. 90). A glance at the Table gives the impression that there 


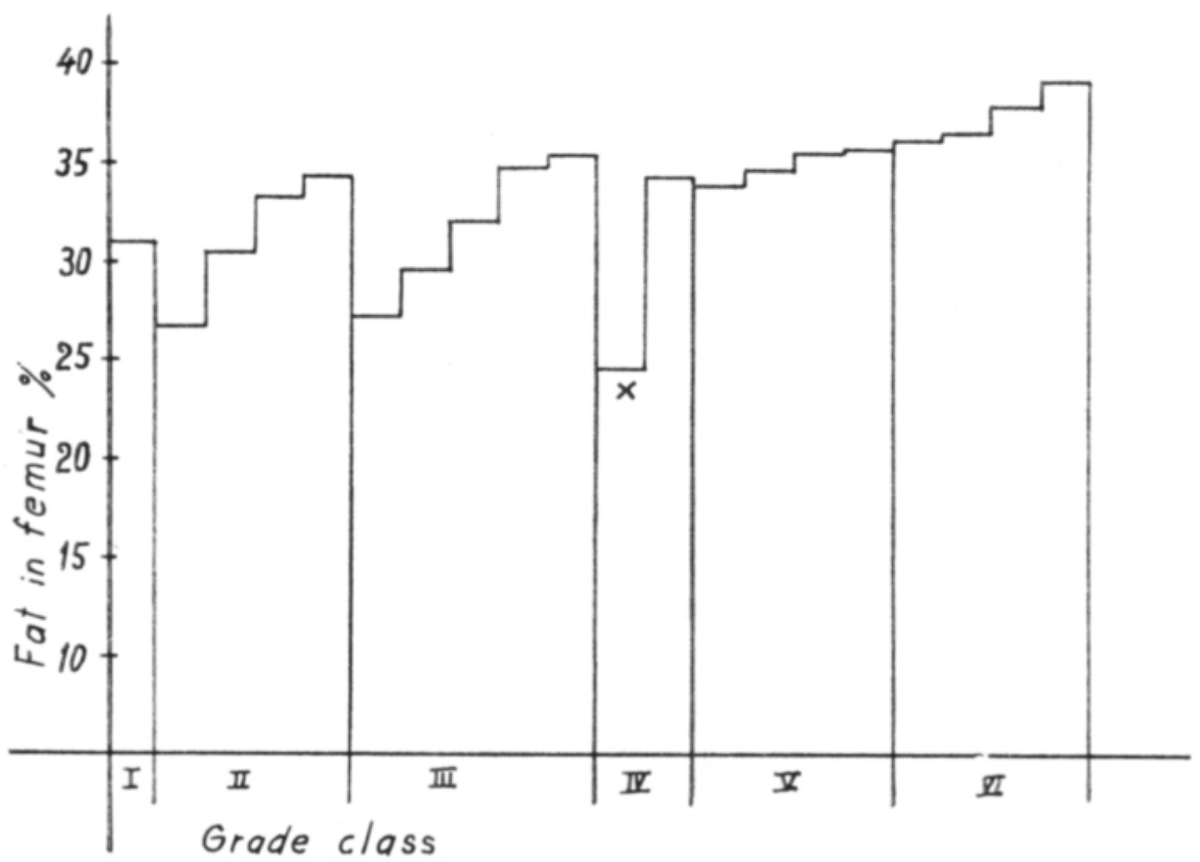

Fig. 1. The femur fat percentages in different grade classes. Every column represents one cow. ${ }^{*}$ The sick cow.

does not exist any positive correlation between the fatness of the cow and the fat content of the femur. This impression is not only confirmed by Fig. 1, but the graph further suggests that there exists a negative correlation. It appears that no cow in the better classes reaches the femur-fat- $\%$ of any cow in class VI, and only some cows in the classes II-IV narrowly surpass the two cows of class V. When we calculate the average femur-fat- $\%$ for the grade classes with more than two cows the following figures are obtained:

II $31.3 \%$, III $31.8 \%$, V $34.9 \%$, VI $37.5 \%$

It is worthy of notice that the sick cow (No. 21) had an exceptionally low femurfat- $\%$.

Table 3 shows the composition of the tibias in four cows. The same cows occur also in Table 2. There seems to exist a fair correlation between the fat contens of tibia and that of femur, and the figures in Table 3 even suggest a negative correlation between the grade class of the cow and the fat content of the tibia. The sick cow (No. 21), however, had less fat in the tibia than corresponds to its grade class.

Table 4 shows that in the newborn calf the fat content of the femur is almost zero. Two days later the femur already contains some fat and a heifer at the age of 10 months does not differ in this respect from the cows.

If we suppose that the volume of an individual bone in a healthy full grown but not very old animal does not alter, one must conclude that an absolute increase in the volume of one bone constituent causes a corresponding decrease in the united 
Table 2. The principal results pertaining to the cow femurs.

\begin{tabular}{|c|c|c|c|c|c|c|c|c|}
\hline \multirow{2}{*}{$\begin{array}{l}\text { Cow } \\
\text { No. }\end{array}$} & \multirow{2}{*}{$\begin{array}{c}\text { Weight } \\
\text { of } \\
\text { cow } \\
\text { kg }\end{array}$} & \multirow{2}{*}{$\begin{array}{c}\text { Grade } \\
\text { of } \\
\text { fatness }\end{array}$} & \multirow{2}{*}{$\begin{array}{c}\text { Weight } \\
\text { of } \\
\text { femur } \\
\text { g }\end{array}$} & \multicolumn{4}{|c|}{$\%$ of femur } & \multirow{2}{*}{$\begin{array}{c}\text { Nitrogen } \\
\text { in the } \\
\text { glue } \\
\%\end{array}$} \\
\hline & & & & fat & protein & ash & water & \\
\hline 22 & 430 & VI & 1748 & 38.9 & 15.0 & 30.1 & 16.0 & 16.9 \\
\hline 12 & 440 & VI & 1744 & 37.3 & 16.3 & 31.7 & 14.6 & 17.3 \\
\hline 6 & 395 & VI & 1375 & 37.0 & 15.9 & 31.8 & 15.3 & 17.4 \\
\hline 2 & 335 & VI & 1260 & 36.8 & 15.5 & 31.9 & 15.9 & 17.2 \\
\hline 20 & 440 & V & 1502 & 35.7 & 16.1 & 33.8 & 14.4 & 17.3 \\
\hline 5 & 450 & V & 1834 & 35.7 & 15.8 & 33.8 & 14.8 & 17.9 \\
\hline 18 & 495 & III & 1787 & 35.4 & 16.6 & 34.0 & 14.0 & 17.2 \\
\hline 14 & 535 & III & 1659 & 34.9 & 16.2 & 33.3 & 15.6 & 17.2 \\
\hline 24 & 345 & V & 1312 & 34.5 & 16.9 & 34.8 & 13.8 & 16.7 \\
\hline 11 & 574 & II & 2024 & 34.3 & 17.7 & 33.9 & 14.2 & 17.4 \\
\hline 15 & 400 & IV & 1451 & 34.1 & 16.8 & 34.5 & 14.6 & 17.2 \\
\hline 1 & 490 & V & 1556 & 33.7 & 16.7 & 34.2 & 15.4 & 16.6 \\
\hline 4 & 520 & II & 1770 & 33.2 & 17.0 & 35.7 & 14.1 & 17.2 \\
\hline 3 & 500 & III & 1661 & 32.0 & 18.5 & 36.0 & 13.5 & 17.5 \\
\hline 19 & 555 & I & 1462 & 31.0 & 17.6 & 37.7 & 13.6 & 17.3 \\
\hline 17 & 551 & II & 1719 & 30.9 & 17.6 & 37.3 & 14.2 & 17.6 \\
\hline 8 & 550 & III & 1829 & 29.4 & 19.1 & 37.8 & 13.8 & 16.9 \\
\hline 23 & 595 & III & 1860 & 27.2 & 21.6 & 39.9 & 11.3 & 17.1 \\
\hline 16 & 560 & II & 1938 & 26.9 & 19.9 & 39.4 & 13.9 & 17.5 \\
\hline 21 & 457 & IV & 1956 & 24.8 & 18.7 & 39.5 & 17.0 & 17.6 \\
\hline Mean & 481 & III & 1672 & 33.2 & 17.3 & 35.1 & 14.5 & 17.2 \\
\hline
\end{tabular}

volume of the others. In composing Table 5 we have used the following density figures: bone minerals 3.2 , protein 1.4 , fat 0.9 . As density of bone minerals that of apatite has been used. Table 5 shows the composition of cow femurs on the volume basis. The cows are listed in the same order as in Table 2. The accumulation of fat into the bone must occur at the expense of protein, ash and/or water. If these constituents give place to the fat proportionally, the composition of the fat-free bone remains unaltered. If the fat replaces only one of the other constituents, the volume percentage of this one in the fat-free bone is the smaller the greater the supplemental fat volume. Table 6 gives the impression that the accumulation of fat in the femur happens at the expense of both protein and ash. Table 7 gives the average volume- $\%$ composition of the femur separately for the 5 first and 5 last cows in Table 5. However, the sick cow (No. 21) has been omitted. Table 7 indicates, in accordance with Table 6, that the fat replaces both protein and ash, and this replacement seems to occur in the same rather constant mutual ratio in which these constituents occur in the bone.

There is a weak point in the performance of the analyses. During the time used for scraping the bones free from flesh and tendons some water evaporates from the bones with the consequence that the water percentages obtained are somewhat too low. Correspondingly, the fat, protein and ash contents will be slightly 
Table 3. The principal results pertaining to the cow tibias.

\begin{tabular}{|c|c|c|c|c|c|c|c|c|}
\hline \multirow{2}{*}{$\begin{array}{l}\text { Cow } \\
\text { No. }\end{array}$} & \multirow{2}{*}{$\begin{array}{c}\text { Weight } \\
\text { of } \\
\text { cow } \\
\text { kg }\end{array}$} & \multirow{2}{*}{$\begin{array}{c}\text { Grade } \\
\text { of } \\
\text { fatness }\end{array}$} & \multirow{2}{*}{$\begin{array}{l}\text { Weight } \\
\text { of } \\
\text { tibia } \\
\text { g }\end{array}$} & \multicolumn{4}{|c|}{$\%$ of tibia } & \multirow{2}{*}{$\begin{array}{c}\text { Nitrogen } \\
\text { in the } \\
\text { glue } \\
\%\end{array}$} \\
\hline & & & & fat & protein & ash & water & \\
\hline 22 & 430 & VI & 1102 & 29.6 & 17.9 & 37.5 & 15.0 & 16.9 \\
\hline 24 & 345 & V & 830 & 28.2 & 18.6 & 40.5 & 12.7 & 16.9 \\
\hline 23 & 595 & III & 1138 & 21.7 & 20.4 & 43.8 & 14.1 & 17.2 \\
\hline 21 & 457 & IV & 1210 & 20.1 & 20.0 & 44.8 & 15.7 & 17.4 \\
\hline Mean & 457 & & 1070 & 24.9 & 19.2 & 41.5 & 14.4 & 17.1 \\
\hline
\end{tabular}

Table 4. The principal results pertaining the femurs of young animals.

\begin{tabular}{|c|c|c|c|c|c|c|c|c|c|c|}
\hline \multirow[t]{2}{*}{ The animal } & \multirow{2}{*}{\multicolumn{2}{|c|}{ Age }} & \multirow{2}{*}{$\begin{array}{c}\text { Weight } \\
\text { kg }\end{array}$} & \multirow{2}{*}{$\begin{array}{c}\text { Grade of } \\
\text { fatness } \\
g\end{array}$} & \multirow{2}{*}{$\begin{array}{c}\text { Weight of } \\
\text { femur } \\
\mathrm{g}\end{array}$} & \multicolumn{4}{|c|}{$\%$ of femur } & \multirow{2}{*}{$\begin{array}{c}\text { Nitrogen } \\
\text { in the } \\
\text { glue } \\
\% \\
\end{array}$} \\
\hline & & & & & & fat & protein & ash & water & \\
\hline Heifer & 10 & months & 271 & III & 1354 & 34.4 & 15.6 & 27.9 & 22.1 & 17.3 \\
\hline Calf & 4 & , & 105 & III & 747 & 22.2 & 17.3 & 21.5 & 39.0 & 16.1 \\
\hline Calf & & days & 35 & & 326 & 0.7 & 17.5 & 14.1 & 67.7 & 15.5 \\
\hline Calf & & ewborn & 33 & & 330 & 0.1 & 16.9 & 15.8 & 67.2 & 17.7 \\
\hline
\end{tabular}

Table 5. The composition of cow femurs as volume percentages.

\begin{tabular}{rrrrr} 
Cow Fat & Protein & Ash & Water \\
\hline & & & 20.3 \\
12 & 54.5 & 13.5 & 11.7 & 18.8 \\
6 & 53.5 & 15.0 & 12.7 & 19.7 \\
2 & 52.9 & 14.7 & 12.7 & 20.5 \\
20 & 52.5 & 14.3 & 12.7 & 19.0 \\
5 & 52.0 & 15.2 & 13.8 & 19.5 \\
18 & 52.0 & 14.8 & 13.7 & 18.5 \\
14 & 51.9 & 15.7 & 13.9 & 20.5 \\
24 & 50.8 & 15.2 & 13.5 & 18.4 \\
11 & 51.1 & 16.1 & 14.4 & 18.8 \\
15 & 50.5 & 16.8 & 13.9 & 19.4 \\
1 & 50.4 & 16.0 & 14.2 & 20.4 \\
4 & 49.7 & 15.8 & 14.1 & 19.0 \\
3 & 49.7 & 16.4 & 14.9 & 18.3 \\
19 & 48.4 & 18.0 & 15.3 & 18.8 \\
17 & 47.6 & 17.4 & 16.2 & 20.0 \\
8 & 47.2 & 17.3 & 16.0 & 19.2
\end{tabular}


Table 6. The volume- $\%$ composition of fat-free femurs.

\begin{tabular}{|c|c|c|c|c|c|c|}
\hline \multirow[t]{2}{*}{$\begin{array}{c}\text { Cow } \\
\text { No. }\end{array}$} & \multirow{2}{*}{$\begin{array}{l}\text { Vol.- \% } \\
\text { fat in } \\
\text { femur }\end{array}$} & \multicolumn{3}{|c|}{ Vol.- $\%$ of fat-free femur } & \multirow{2}{*}{$\frac{\text { protein }}{\text { ash }}$} & \multirow{2}{*}{$\frac{\text { protein }}{\text { water }}$} \\
\hline & & protein & ash & water & & \\
\hline 22 & 54.5 & 29.7 & 25.8 & 44.5 & 1.15 & 0.67 \\
\hline 12 & 53.5 & 32.2 & 27.2 & 40.6 & 1.18 & 0.79 \\
\hline 6 & 52.9 & 31.1 & 27.0 & 41.9 & 1.15 & 0.74 \\
\hline 2 & 52.5 & 30.1 & 26.8 & 43.1 & 1.12 & 0.70 \\
\hline 20 & 52.0 & 31.8 & 28.8 & 39.4 & 1.10 & 0.81 \\
\hline 5 & 52.0 & 30.9 & 28.7 & 40.4 & 1.08 & 0.76 \\
\hline 18 & 51.9 & 32.7 & 28.8 & 38.5 & 1.14 & 0.85 \\
\hline 14 & 50.8 & 30.9 & 27.5 & 41.6 & 1.12 & 0.74 \\
\hline 24 & 51.1 & 33.0 & 29.4 & 37.6 & 1.12 & 0.88 \\
\hline 11 & 50.5 & 34.0 & 28.1 & 37.9 & 1.21 & 0.90 \\
\hline 15 & 50.4 & 32.2 & 28.7 & 39.1 & 1.12 & 0.82 \\
\hline 1 & 49.7 & 31.4 & 28.0 & 40.6 & 1.11 & 0.77 \\
\hline 4 & 49.7 & 32.6 & 29.6 & 37.8 & 1.10 & 0.86 \\
\hline 3 & 48.4 & 34.8 & 29.6 & 35.6 & 1.18 & 1.17 \\
\hline 19 & 47.6 & 33.2 & 30.9 & 35.9 & 1.07 & 0.92 \\
\hline 17 & 47.2 & 32.8 & 30.3 & 36.9 & 1.08 & 0.89 \\
\hline 8 & 45.4 & 34.9 & 29.8 & 35.3 & 1.17 & 0.99 \\
\hline 23 & 43.5 & 39.5 & 31.6 & 28.9 & 1.25 & 1.37 \\
\hline 16 & 42.6 & 35.2 & 30.3 & 34.5 & 1.16 & 1.02 \\
\hline 21 & 39.3 & 31.3 & 28.8 & 39.9 & 1.09 & 0.78 \\
\hline
\end{tabular}

Table 7. The average volume- $\%$ composition of the femur a) in 5 cows having most fatty femur and b) in 5 cows having least fatty femur.

\begin{tabular}{cccccc}
\hline Group & Fat & Protein & Ash & Water & $\frac{\text { Protein }}{\text { Ash }}$ \\
\hline a & 53.1 & 14.5 & 12.7 & 19.7 & 1.14 \\
b & 45.3 & 19.3 & 16.8 & 18.8 & 1.15 \\
\hline Difference & +7.8 & -4.8 & -4.1 & +0.9 & $4.8: 4.1=1.17$
\end{tabular}

too high. However, this hardly affects the validity of the conclusions drawn from the results of the study. The preparing of the bones was performed in a common laboratory room. Evidently it would have been better to have an atmosphere practically saturated with water vapour.

\section{Summary and conclusions}

The femurs of 20 cows and 4 young animals have been analysed, similarly the tibias of 4 cows. The whole bone was used as a sample. Fat, protein and ash were directly determined and the water content was calculated as difference. By 
a visual estimate the animals were classified in grade classes using a system in which class I denotes very fat cows and class VII emaciated animals.

The average percent composition of the cow femurs was as follows. The ranges of variation are given in brackets. A sick cow is omitted.

$\begin{array}{lll}\text { Fat } & 33.6 & (26.9-38.9) \\ \text { Protein } & 17.2 & (15.0-21.6) \\ \text { Ash } & 34.8 & (30.0-39.9) \\ \text { Water } & 14.4 & (11.3-16.0)\end{array}$

There seems to be a negative correlation between the fatness of the cow and the fat content of the femur. However, a closer examination of the results, and especially the examination of the volume- $\%$ composition of the femurs, suggests that the accumulation of fat in the bone results from the withdrawal of ash and protein which are the firmness and tenacity giving components in the bone. Probably the cows of the better grade classes have been in better condition not only as regards their fat deposits and musculature but also in regard to the minerals in the bones. Thus a high fat content in the bones is no positive indication of a healthy condition in an animal.

The protein content in the femurs of young animals is about the same as that in cow femurs. The water content is high but that of fat and ash low. The femur of a newborn calf was almost fat-free, but the fat and mineral contents seem to increase rapidly already in early life.

The investigated tibias contained more protein and ash but less fat than the femurs of the same cows.

This study does not afford support to the opinion expressed e.g. by MAYNARD and Loosli (1 p. 126) that the fat in the bones the same manner as the adipose tissues in general, serves the animal as energy reserve during scanty feeding. The fat in the bones seems not to decrease when the animal becomes thinner but this probably occurs when the nutritional state pertaining to minerals and vitamins is improved.

R E F E R E N C S

(1) Maynard, L.A. \& Loosli, J.K. 1962. Animal Nutrition. 5th ed. New York - Toronto - London: $1-533$.

(2) Palohermo, L. 1944. Über die Zusammensetzung des Körpers der Milchkühe. Acta Agr. Fenn. 56, 1: $1-63$. 


\section{LUIDEN KEMIALLISESTA KOOSTUMUKSESTA}

\section{Paloheimo, L. M. Björkenheim ja H. Leivonen}

\section{Kotieläintieteen laitos, Helsingin Yliopisto}

Kahdenkymmenen lehmän sekä neljän nuoren naudan oikeanpuoleisesta reisiluusta määritettiin rasva, valkuainen, tuhka ja vesi. Samoin tutkittiin neljän lehmän sääriluu. Lehmien lihavuuskunto arvosteltiin. Tutkimuksessa kåvi ilmi, että lihavien lehmien reisiluut olivat vähärasvaisempia kuin laihojen. Kysymyksessä ei kuitenkaan näytä olevan välitön negatiivinen vuorosuhde lihavuuskunnon ja luiden rasvapitoisuuden välillä. Tutkimustuloksien lähempi tarkastelu näet osoitti, että rasvan lisääntyminen luussa tapahtuu kivennäisaineksen ja valkuaisen, siis luille lujuutta ja sitkeyttä antavien aineiden kustannuksella. Rasvan lisääntyminen luussa on siis merkki luiden kivennäis- ja valkuaisköyhtymisestä. Ilmeisestikin hyvän lihavuuskunnon omanneet tutkitut lehmät olivat olleet myös kivennäis-, valkuais- ja D-vitamiiniravitsemukseen nähden parempikuntoisia kuin laihat eläimet.

Koska kaikkein laihimmilla lehmillä oli luissa eniten rasvaa, voidaan tuskin pitää todennäköisenă, että luiden rasva toimisi eläimen vararavintona samaan tapaan kuin muu kudosrasva.

Lehmien reisiluussa tavattiin rasvaa $27-39 \%$, vastasyntyneellä vasikalla vastaavasti $0.1 \%$, 2 päivää vanhalla $0.7 \%$ ja neljän kuukauden ikäisellä $22 \%$. Kymmenen kuukauden ikäisen hiehon reisiluussa oli rasvaa $34 \%$. Ilmeisestikin naudan luiden rasvapitoisuus lisääntyy nopeasti ja saavuttaa täysikasvuiselle ominaisen arvon jo ensimmäisen elinvuoden kuluessa. Lehmien sääriluun rasvaprosentti vaihteli $20-30$. 